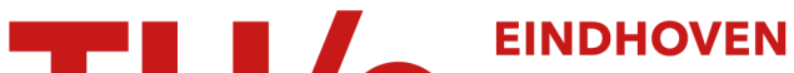 UNIVERSITY OF TECHNOLOGY
}

\section{The autoderivatization of 4-ketocyclophosphamide during capillary gas chromatography}

Citation for published version (APA):

Bruijn, de, E. A., Leclercq, P. A., \& Tjaden, U. R. (1986). The autoderivatization of 4-ketocyclophosphamide during capillary gas chromatography. HRC \& CC, Journal of High Resolution Chromatography and

Chromatography Communications, 9(2), 89-94. https://doi.org/10.1002/jhrc.1240090207

DOI:

10.1002/jhrc.1240090207

Document status and date:

Published: 01/01/1986

\section{Document Version:}

Publisher's PDF, also known as Version of Record (includes final page, issue and volume numbers)

\section{Please check the document version of this publication:}

- A submitted manuscript is the version of the article upon submission and before peer-review. There can be important differences between the submitted version and the official published version of record. People interested in the research are advised to contact the author for the final version of the publication, or visit the $\mathrm{DOI}$ to the publisher's website.

- The final author version and the galley proof are versions of the publication after peer review.

- The final published version features the final layout of the paper including the volume, issue and page numbers.

Link to publication

\section{General rights}

Copyright and moral rights for the publications made accessible in the public portal are retained by the authors and/or other copyright owners and it is a condition of accessing publications that users recognise and abide by the legal requirements associated with these rights.

- Users may download and print one copy of any publication from the public portal for the purpose of private study or research.

- You may not further distribute the material or use it for any profit-making activity or commercial gain

- You may freely distribute the URL identifying the publication in the public portal.

If the publication is distributed under the terms of Article 25fa of the Dutch Copyright Act, indicated by the "Taverne" license above, please follow below link for the End User Agreement:

www.tue.nl/taverne

Take down policy

If you believe that this document breaches copyright please contact us at:

openaccess@tue.nl

providing details and we will investigate your claim. 


\title{
The Autoderivatization of 4-Ketocyclophosphamide during Capillary Gas Chromatography
}

\author{
E. A. de Bruijn* \\ Leiden University Medical Centre, Department of Clinical Oncology, Sylvius Laboratories, Wassenaarseweg 72, 2333 AL Leiden, \\ The Netherlands
}

\section{P. A. Leclercq}

Laboratory of Instrumental Analysis, Department of Chemical Engineering, Eindhoven University of Technology, P.O. Box 513, 5600 MB Eindhoven, The Netherlands

\section{U. R. Tjaden}

Centre for Biopharmaceutical Sciences, Division of Analytical Chemistry, Leiden University, The Netherlands

\section{Key Words:}

\author{
Gas chromatography, GC \\ Capillary columns \\ Mass spectrometry \\ Autoderivatization \\ Cyclophosphamide \\ 4-Ketocyclophosphamide
}

\section{Summary}

The selectivity of a capillary gas chromatographic assay for the anti-neoplastic and immunosuppressive agent cyclophosphamide (CPA) towards one of its naturally occurring metabolites, i.e. 4-ketocyclophosphamide (4-keto CPA), has been studied. Mass spectrometry studies showed that a cyclization product of 4-keto-CPA can form using the same chromatographic conditions as those under which CPA was determined. However, the amount produced is relatively small (less than 10\%) compared with the percentage produced from CPA. Furthermore, both cyclization products, formed by loss of $\mathrm{HCl}$ and intraalkylation of the parent compounds, can be separated well under suitable chromatographic conditions.

\section{Introduction}

Cyclophosphamide [N,N-bis(2-chlorethyl)-tetrahydro- $2 \mathrm{H}$ 1,3,2-oxazaphosphorin-2-amine-2-oxide] (Figure 1) is an alkylating agent with a broad spectrum of activity against tumors in humans, and is probably the best overall agent for immunosuppression [1,2]. The biological properties of CPA are mediated by the compounds generated from the metabolism of this drug. CPA is activated by hepatic mixed function oxidases to a wide variety of active metabolites (Figure 3) [3]. Metabolites of main interest are 4-hydroxy CPA, 4-keto-CPA, CPE and PM. 4-Hydroxy-CPA is believed by most investigators of the mechanisms of action of CPA to be the primary extracellular mediator of antitumor activity [4]. PM is thought to be both an extra- and an intracellular acting mediator with antitumor activity [5], while recently, an important role for imino-CPA was described [6].

Based on a paper presented at the Sixth International Symposium on Capillary Chromatography.

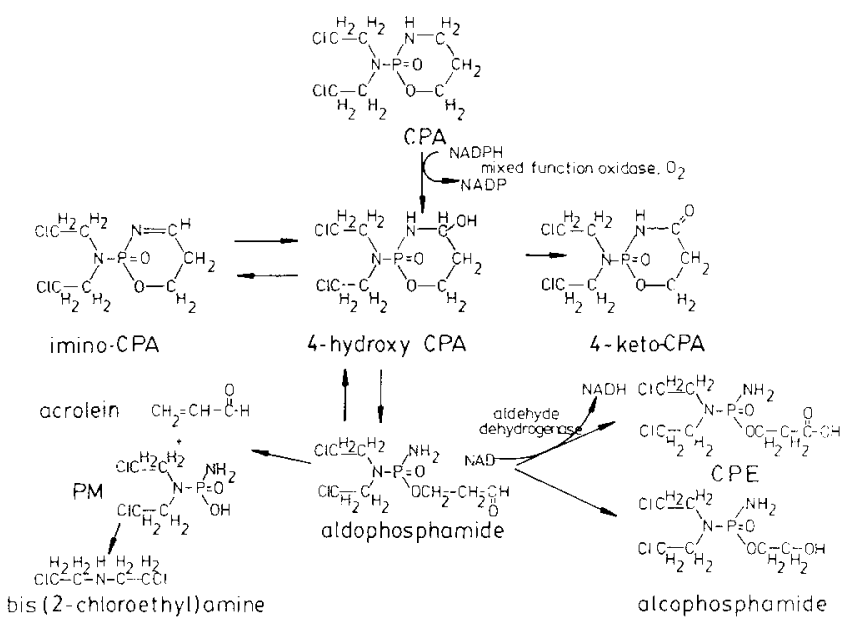

Figure 1

Metabolic conversion of CPA.

Metabolism by hepatic microsomal enzymes depends on numerous factors including age, co-administration of drugs, heredity, chronobiological effects, and disease state (cancer patients) $[8,9]$. The pharmacokinetics and metabolism of CPA have been found to vary widely $[10,11]$; individual adjustment of dosage based on monitoring unchanged CPA and metabolites could provide an optimized therapeutic efficacy and minimized toxicity. This requires sensitive and selective assays for CPA and metabolites. To date, methods of analysis include radioactivity measurements of ${ }^{14} \mathrm{C}$-labeled CPA [12], mass

Abbreviations used are: CPA: cyclophosphamide, 4-hydroxy CPA: 4 hydroxycyclophosphamide, 4-keto-CPA: 4-ketocyclophosphamide, CPE carboxyphosphamide, PM: phosphoramide mustard, imino CPA: imino cyclophosphamide, Rt: retention time. 
<smiles>O=P1(N(CCCl)CCCl)NCCOP12(NCCCl)OCCCN2CC(Cl)(Cl)Cl</smiles>
CPA

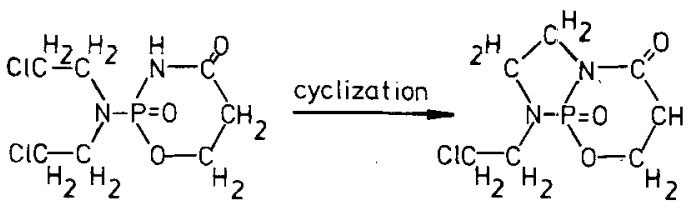

4-keto-CPA

Figure 2

Cyclization processes of CPA and 4-keto-CPA following injection on capillary gas chromatography.

spectrometry [13], gas chromatography-mass spectrometry $[14,15]$, gas-liquid chromatography, both with and without derivatization [16-20], high performance liquid chromatography [21], and high performance liquid chromatography-field desorption mass spectrometry [22]. Since radiolabeling is clinically inconvenient and techniques using mass spectrometry hamper routine application in extensive pharmacological studies, gas chromatography with nitrogen phosphorus specific detection and high performance liquid chromatography seem attractive methods [16-21]. Furthermore, derivatization is timeconsuming and then assays not requiring derivatization techniques seem to be preferable [17-21]. The derivatization of CPA during capillary gas chromatography is based on autoderivatization of CPA by intramolecular alkylation, depending on injection and column temperatures and injected amounts of CPA [14,18] (Figure 2). The selectivity of these assays with respect to other drugs regularly combined with CPA has been established. The gas chromatographic assay described by our group enables a good separation of 4-keto-CPA in presence of CPA itself, CPE, and other compounds of interest [20]. However, taking metabolites into account (Figure 1), products such as cyclization product of CPA on which the determination of CPA is based (Figure 2) could be formed and therefore interfere with the CPA assay.

Since 4-hydroxy-CPA and imino-CPA are assumed to be unstable and rapidly changed into 4-keto-CPA and/or CPE, a cyclization product of 4-keto-CPA only could result in a serious hindrance for the determination of CPA by measuring CPA's cyclization product. Besides possible interferences of 4-keto-CPA with the determination of CPA, another point needs further attention: the peak of 4-ketoCPA was quite different from neighboring peaks ([20], see also Figure 3).

The present investigations are the first in a series intended to gain more insight into the behavior of the CPA metabolite 4-keto-CPA during capillary gas chromatography and its

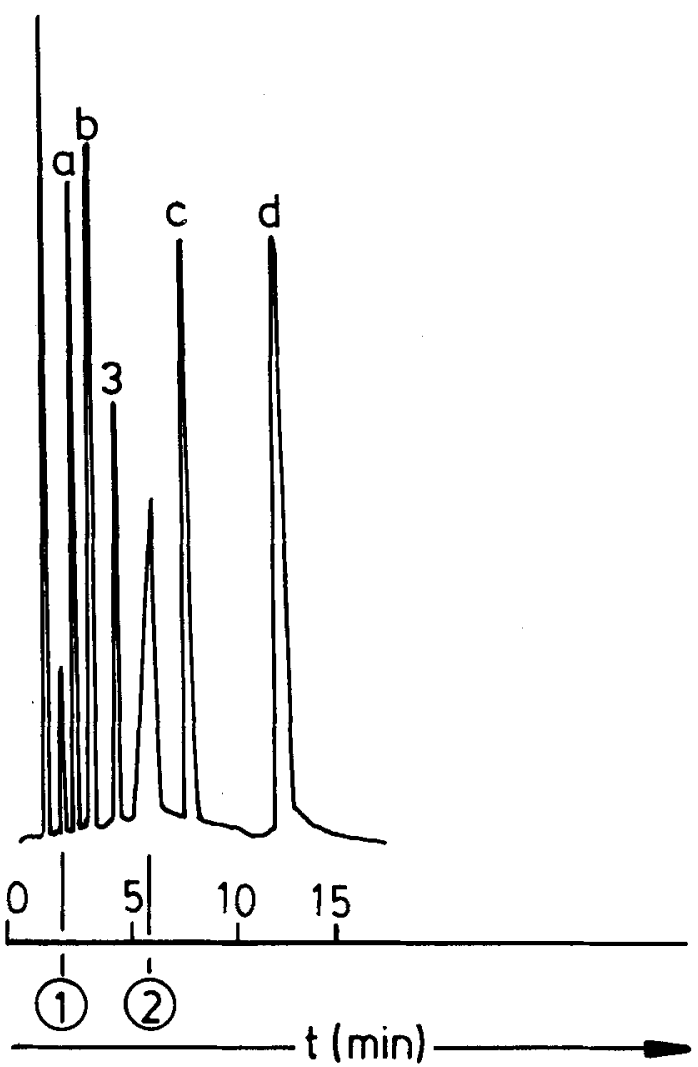

Figure 3

A chromatogram of 4-keto-CPA (2), the cyclization product of 4-ketoCPA (1), CPA (a), the cyclization product of CPA (3), and of compounds not related with CPA, (b, c, and d). ASCOT OV-275 capillary column was used ( $10 \mathrm{~m} \times 0.31 \mathrm{~mm}$ i.d.). Temperature: programmed from 205 to $220^{\circ} \mathrm{C}$ at $2 \% \mathrm{~min}$. Temperature program started $9 \mathrm{~s}$ after injection.

possible interference in the gas chromatographic determination of CPA itself.

\section{Experimental}

Chemicals. CPA and metabolites including 4-keto-CPA were kindly supplied by ASTA-Werke (Bielefeld, FRG). All solvents were of analytical grade and obtained from Baker (Deventer, The Netherlands) and Merck (Darmstadt, FRG).

Gas Chromatography. For routine measurements, two gas chromatographs were used: a Packard Becker Model 420 (Packard Becker, Delft, The Netherlands), equipped with a Model 18-789 nitrogen-phosphorus selective detector (Hewlett-Packard, Avondale, PA, USA), and a HewlettPackard Model $5713 \mathrm{~A}$, equipped with a ${ }^{63} \mathrm{Ni}$ puisemodified electron-capture detector. The samples were introduced onto the column by means of a solid-sample injection system [18-20].

Columns. Support-coated open-tubular (SCOT) OV-275 columns ( $7 \mathrm{~m} \times 0.31 \mathrm{~mm}$ i.d.), made of Duran 50 glass, were used when routine analyses were carried out for clinical pharmacological studies. A more detailed description was 
reported recently by us [20], including temperatures of injection, columns, and detection systems. For mass spectrometry a fused silica WCOT CP SIL-5CB column $(25 \mathrm{~m} \times 0.21 \mathrm{~mm}$ i.d.) was used.

Mass Spectrometry. A Finnigan Model 4000 quadrupole mass spectrometer (Finnigan, Sunnyvale, CA, USA) was used both in the electron impact (El) and chemical ionization $(\mathrm{Cl})$ mode. The mass spectral data presented were acquired under the following conditions: ionizing electron energy, $70 \mathrm{eV}$; electron current, $0.30 \mathrm{~mA}$; scan time, $1 \mathrm{~s}$ per scan; source temperature, $250^{\circ} \mathrm{C}(\mathrm{EI})$ and $200^{\circ} \mathrm{C}(\mathrm{Cl})$. For the $\mathrm{Cl}$ mode, $\mathrm{NH}_{3}$ reactant gas was introduced via the make-up gas line. The ion source was maintained at 0.15 Torr gauge reading. The WCOT fused silica column was directly inserted into the ion source. The column was operated isothermally. Samples were dissolved in ethyl acetate and injected onto the column at $250^{\circ} \mathrm{C}$ (falling needle) and $83^{\circ} \mathrm{C}$ (on-column).

\section{Results and Discussion}

A chromatogram of 4-keto-CPA and CPA using a capillary SCOT OV-275 column and ECD detection is presented in Figure 3. A good separation between the cyclization product of CPA and noncyclized 4-keto-CPA was obtained. A broad peak of 4-keto-CPA was observed compared with neighboring peaks.

\subsection{GC/(EI) Mass Spectrometry}

A total ion current chromatogram of 4-keto-CPA using split injection at $250^{\circ} \mathrm{C}$ onto a fused silica WCOT column coated with a nonpolar phase is shown in Figure 4. Two peaks can be distinguished with $R_{t}=4.5 \mathrm{~min}$ and $R_{t}=7.0 \mathrm{~min}$. The peak area ratio peak 1: peak 2 under the described conditions, as determined by peak integration, was 0.08 . Furthermore, asymmetric peaks were encountered in contrast to the peaks obtained with OV-275 capillary columns (Figure 4 versus Figure 3 ).

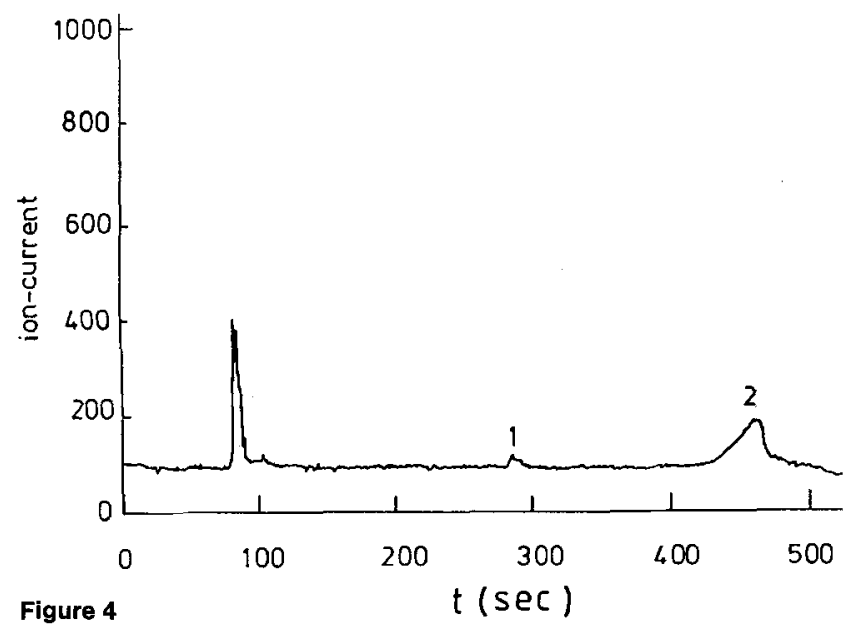

Total ion current chromatogram of 4-keto-CPA using solid injection at $250^{\circ} \mathrm{C}$. Fused silica WCOT CP Sil-5 column $(25 \mathrm{~m} \times 0.21 \mathrm{~mm}$ i.d. $)$ at $230^{\circ} \mathrm{C}$.

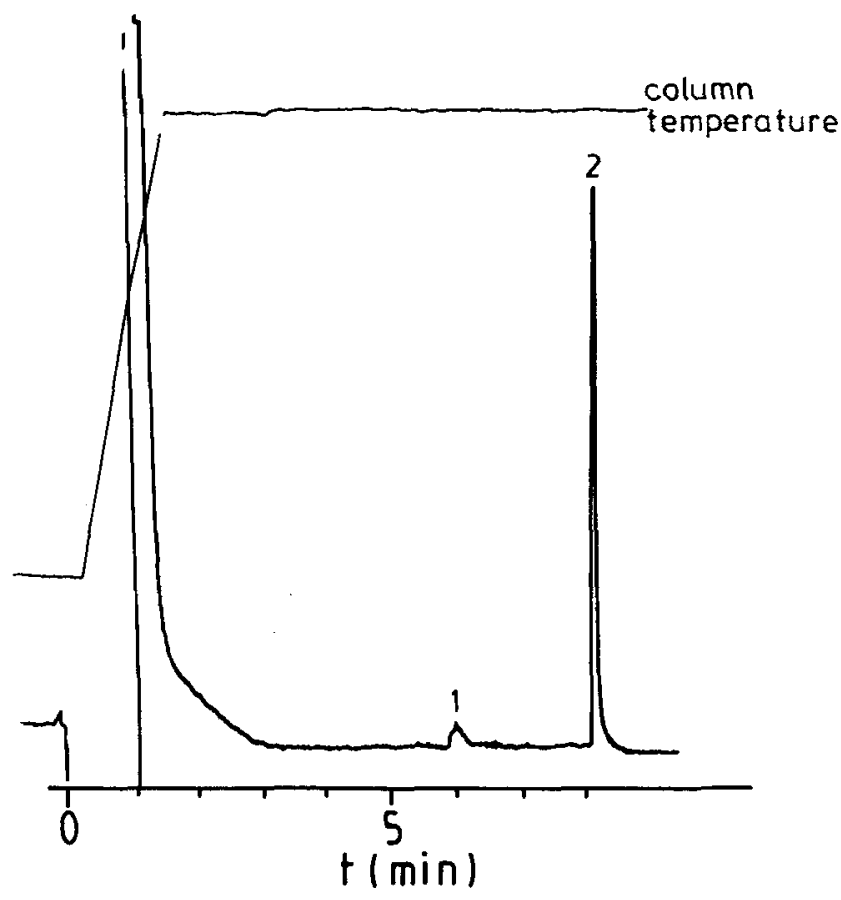

Figure 5

A chromatogram of 4-keto CPA after on-column injection at $83^{\circ} \mathrm{C}$. Temperature program from $83^{\circ} \mathrm{C}$ to $225^{\circ} \mathrm{C}$ at $1.5^{\circ} / \mathrm{s}$. Otherwise similar conditions as described for Figure 4.

A chromatogram obtained after on-column injection at $83^{\circ} \mathrm{C}$ under otherwise similar conditions is shown in Figure 5. Two peaks with $R_{t}=6.1 \mathrm{~min}$ and $R_{t}=8.3$ min were observed. The peak area ratio peak 1: peak 2 was less than 0.05 . Much less asymmetry was observed for the second peak. These results suggest that degradative cyclization occurs in the injector as well as on the column. The latter effect, on-column reaction, could be distinguished by a slightly raised baseline between peaks 1 and 2 in Figure 5 .

\subsection{El Mass Spectral Fragmentation}

The El mass spectrum of peak 1 is given in Figure 6 a. Fragment ions at $\mathrm{m} / \mathrm{z} 189,161$, and 117 were formed. These ions are degradation products of the $\mathrm{M}^{+}$ion at $\mathrm{m} / \mathrm{z} 238$, which was not observed due to rapid conversion to the molecular ion at $\mathrm{m} / \mathrm{z} 189$ by loss of $\mathrm{CH}_{2} \mathrm{Cl}$ under the $\mathrm{El}$ conditions described.

The El mass spectrum of peak 2 is given in Figure $6 \mathrm{~b}$. lons at $\mathrm{m} / \mathrm{z} 225,189,163,161,134,117$, and 92 are formed. The fragmentation processes, together with their percentages, as obtained from El mass spectrometry of both peaks 1 and 2 , are presented in scheme 1.

\subsection{Cl Mass Spectral Fragmentation}

The $\mathrm{Cl}$ mass spectrum of peak 1 is given in Figure 7a. Apart from the protonated molecular ion $\mathrm{MH}^{+}$at $\mathrm{m} / \mathrm{z} 239$, the $\mathrm{MNH}_{4}{ }^{+}$ion at $\mathrm{m} / \mathrm{z} 256$ is formed. The $\mathrm{Cl}$ mass spectrum of 

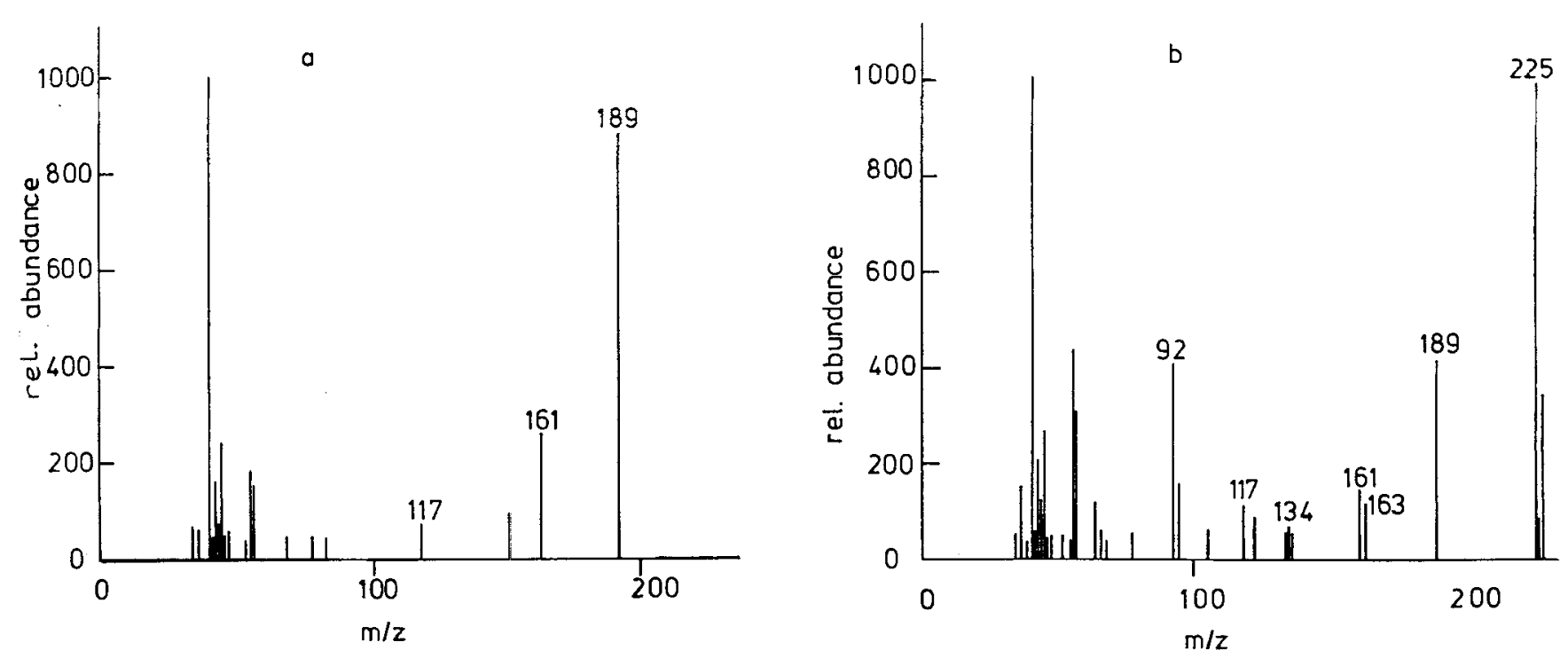

Figure 6

El mass spectra of a) peak 1 and b) peak 2 as presented in Figure 4.

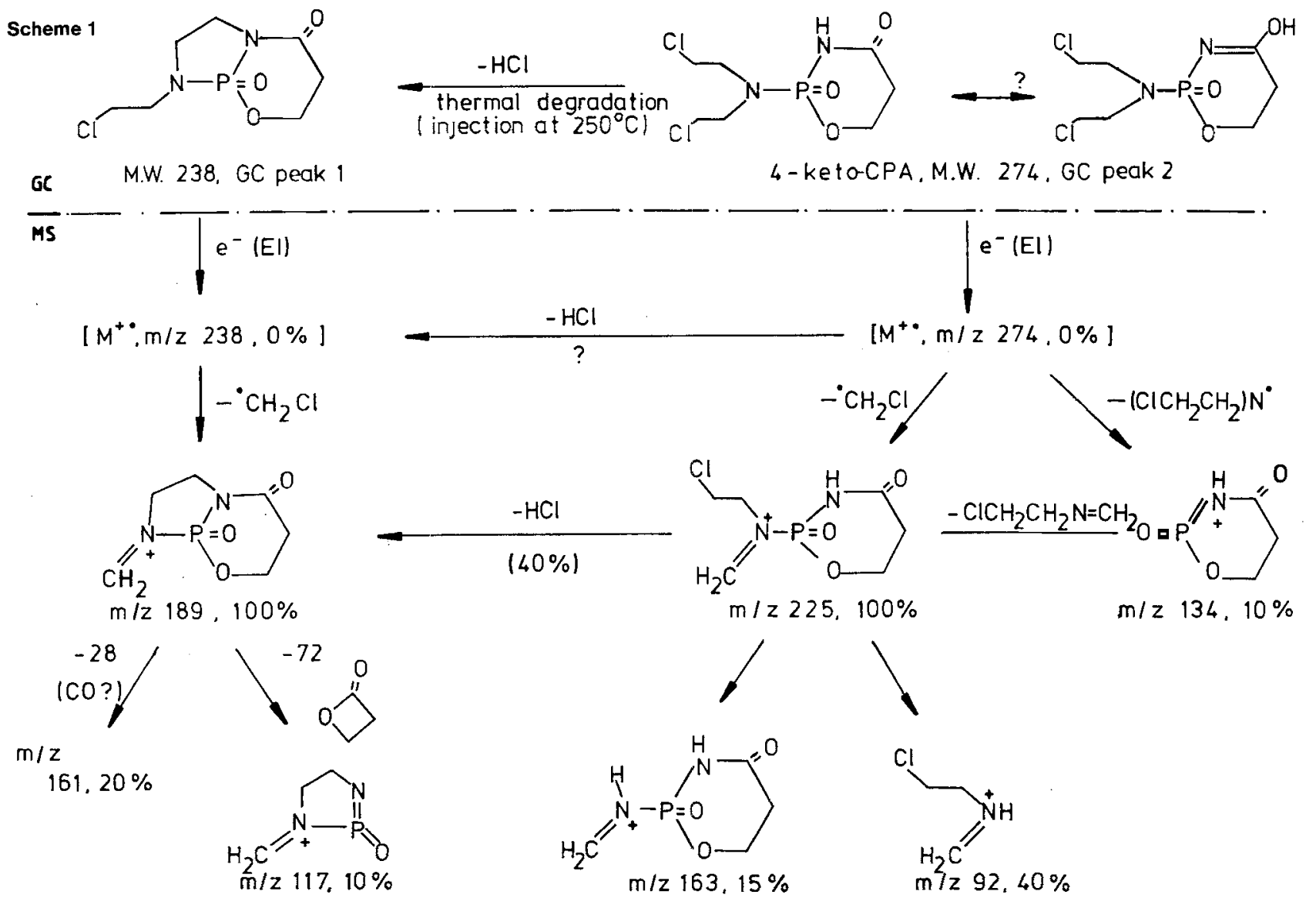

peak 2 is given in Figure $7 b . \mathrm{MH}^{+}, \mathrm{m} / \mathrm{z} 275$ and $\mathrm{MNH}_{4}{ }^{+}, \mathrm{m} / \mathrm{z}$ 292 were formed; in addition, the fragment ion $\mathrm{MH}^{+}-\mathrm{HCl}$ at $\mathrm{m} / \mathrm{z} 239$ is found.

The pathways of degradation during both capillary GC and $\mathrm{Cl}$ mass spectrometry together with their percentages are presented in scheme 2 .
As schemes 1 and 2 show, peak 1 is related to a cyclization product of 4-keto-CPA, formed under the conditions described for capillary gas chromatography. This product, which is produced in relatively low abundance, could be easily separated from the unchanged 4-keto-CPA. The comparable cyclization product of CPA could be well 

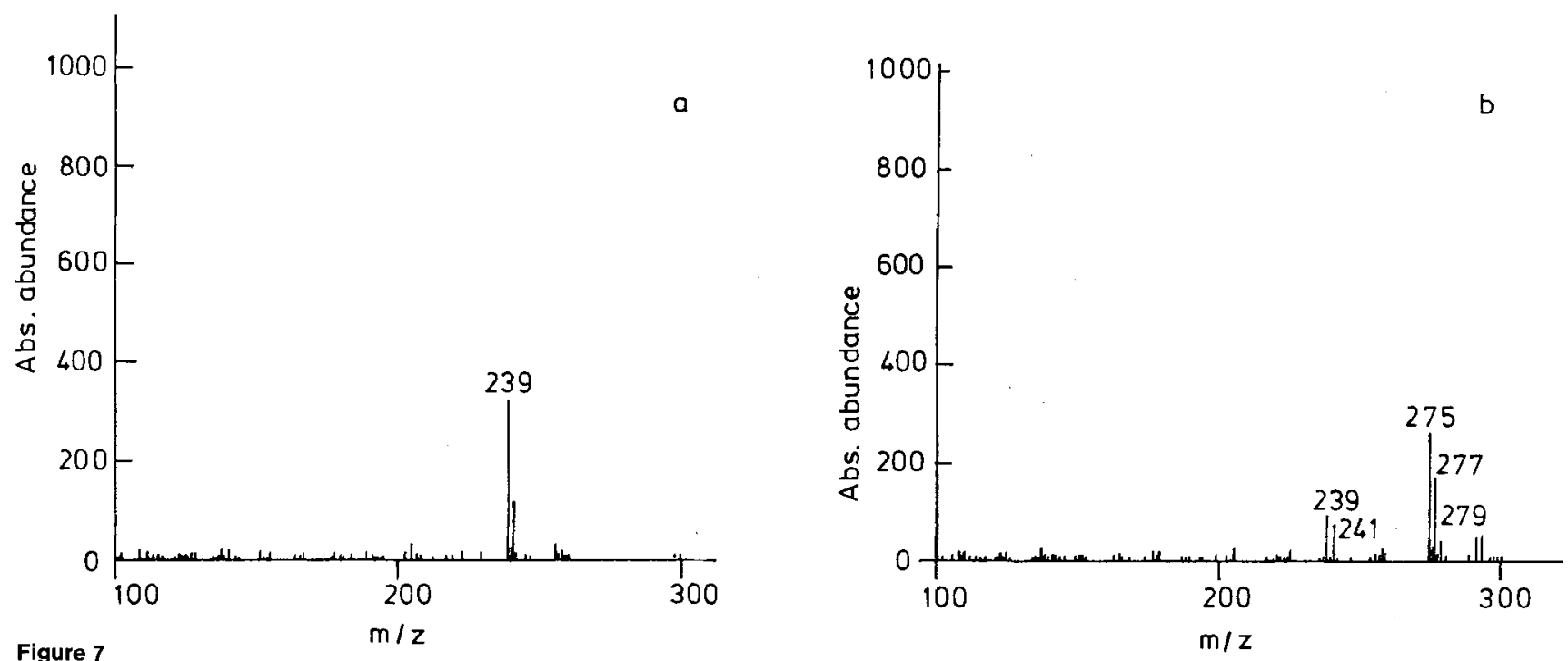

$\mathrm{Cl}$ mass spectra of a) peak 1 and b) peak 2 as presented in Figure 4.

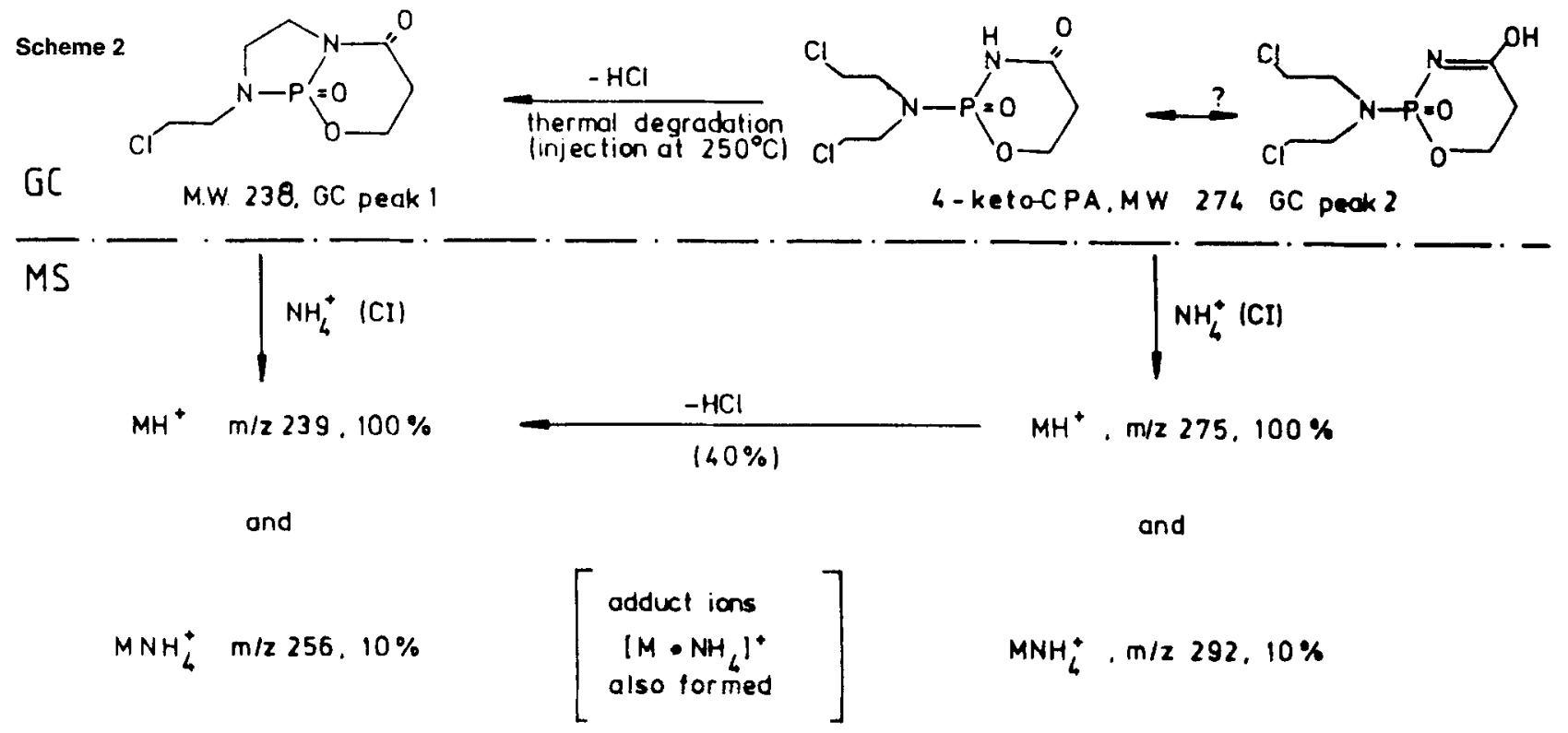

separated from the cyclization product of CPA $[14,18-20]$ (Figure 2). In contrast to CPA cyclization, the product of 4-keto-CPA cyclization is formed in relatively small amounts. Nevertheless, it can be questioned whether the GC assay for CPA, based on cyclization of CPA by a loss of $\mathrm{HCl}$ under suitable chromatographic conditions, is hindered by incomplete separation of the 4-keto-CPA cyclization product. Since 4-keto-CPA has been demonstrated to be a naturally occurring metabolite of CPA using capillary GC without derivatization [20], CPA concentrations as measured by its cyclization product could be too high. On temperature programmed SCOT OV-275 columns, the cyclization product of 4-keto CPA is eluted just after the injection peak or is present in plasma matrix front peaks (Figure 3, [18], [20]. In our opinion, the relatively low abundance of cyclization product of 4-keto-CPA formed during capillary $\mathrm{GC}$ is due to extra stabilization of 4-keto-CPA by keto-enol tautomerism, as depicted in schemes 1 and 2.

\subsection{Thermal Desorption Mass Spectrometry}

Measurements by thermal desorption (EI) mass spectrometry with a fast temperature program $(0.15 \mathrm{~A} / \mathrm{s})$ and by NMR confirmed the existence of keto-enol tautomerism at temperatures below $150^{\circ} \mathrm{C}$; these data will be published separately [24]. The tautomerism could be responsible for the peak asymmetry, using the columns described for mass spectrometry, or peak broadening, as observed when SCOT OV-275 columns were applied [20]. However, the 
4-keto-CPA peak is twice as broad as the neighboring peaks presented in Figure 3: this indicates that absorption of one or both of the compounds of the tautomeric mixture together with the very existence of the tautomerism is responsible for the remarkable peak shape.

\section{Conclusions}

The data obtained from this study show that processes occur during injection capillary gas chromatography of 4-keto-CPA comparable with those on which the assay in blood plasma of CPA is based. A cyclization product of 4-keto-CPA, produced by loss of $\mathrm{HCl}$, was demonstrated by capillary gas chromatography with $\mathrm{El}$ and $\mathrm{Cl}$ mass spectrometry. The amount of the cyclization product of 4-keto CPA produced appeared to be relatively low (less than $10 \%$ ) as opposed to the amount of cyclised CPA produced under identical circumstances.

Probably, keto-enol tautomerism prevents cyclization of 4-keto-CPA in large amounts during capillary gas chromatography; the peak broadening and asymmetry can not be explained by this phenomenon alone.

Both capillary SCOT OV-275 and nonpolar WCOT columns enable sufficient separation of 4-keto-CPA, CPA, and their cyclization products.

\section{Acknowledgment:}

Supported in part by a grant of "Saal van Zwanenbergstichting".

\section{References}

[1] H. Arnold and F. Boerseaux, Angew, Chem. 70 (1958) 539.

[2] J. Holland and E. Frei, III, (Eds.) "Cancer Medicine", Lea \& Febiger, Philadelphia (1973).

[3] B. E. Domeyer and N. E. Sladek, Cancer Res. 40 (1980) 174.

[4] N. Brock and H. J. Hohorst, Z. Krebsforsch. 88 (1977) 185

[5] P. J. Cox, B. J.Philips, and P. Thomas, Cancer Res. 35 (1975) 3755.

[6] C. Fenselau, M.-N. Kan, and S. S. Rau, Cancer Res. 37 (1977) 3738.
[7] R. F. Struck, M. C. Krik, M. H. Witt et al, Biomed. Mass. Spectrom. 2 (1975) 46.

[8] F. Vessell, Clin. Pharmacol. Ther. 22 (1977) 659.

[9] D. D. Breimer, Clin. Pharmacokin. 8 (1983) 371.

[10] P. H. T. J. Slee, E. A. de Bruijn, O. M. J. Driessen, J. Hermans, and A. T. van Oosterom, Anticancer Res. 3 (1983) 269.

[11] H. Mouridsen, O. Farmer, and L. Skovsted, Acta Pharmacol. Toxicol. 35 (1974) 98.

[12] J. Cohen, J. Jao, and W. Jusko, Br. J. Pharmacol. 43 (1971) 677.

[13] U. Bahr, H. R. Schulten, O. R. Hammes, and F. Aerts, Clin. Chim. Acta 103 (1980) 183.

[14] C. Pantarotto, A. Martini, G. Belvedere, M. G. Donelli, A. Frigerid, Cancer Treat. Rep. 60 (1976) 493.

[15] C. Lartigue-Mattei, J. L. Chabard, C. Touzet, H. Bargnoux, J. Petit, and J. A. Berger, J. Chromatogr. 310 (1984) 407.

[16] F. D. Juma, H. J. Rogers, J. R. Trounce, and I. D. Bradbrook, Cancer Chem. Pharmacol. 1 (1978) 229.

[17] T. Fachinetti, M. D. d'Incalci, G. Martinelli, L. Cantoni, G. Belvedere, and M. Salmona, J. Chromatogr. 145 (1978) 315.

[17a] B. Whiting, S. H. K. Miller, and B. Caddy, Brit. J. Clin. Pharmacol. 6 (1978) 373.

[18] N. Van den Bosch and D. de Vos, J. Chromatogr. 183 (1980) 49.

[19] N. Van den Bosch, O. Driessen, A. Emonds et al., Meth. and Exptl. Clin. Pharmacol. 3 (6) (1981) 377.

[20] E. A. de Bruijn, U. R. Tjaden, A. T. van Oosterom, P. Leeflang, and P. A. Leclercq, J. Chromatogr. 279 (1983) 603.

[21] R. W. Hardy, C. Erlichman, and S. J. Soldin, Therapeutic Drug Monitoring 6 (3) (1984) 313.

[22] M. Przybylski, Arzneim.-Forsch/Drug Res. 32 (II) (9) (1982) 995.

[23] P. M. J. van der Berg and T. Cox, Chromatographia 5 (1972) 301.

[24] E. A. de Bruijn, P. A. Leclercq, J.W. de Haan, L. J. M. van de $V e n$, and $U$. R. Tjaden (to be submitted to Biom. Mass Spectrom.). 